\title{
Hubungan Kesepian Dengan Depresi Yang DiModeratori Oleh Religiositas Pada Anak Yatim Pondok Anak Yatim (PAY) As Salman, Malang
}

\author{
Ega Yahya Fadillah \\ Magister Psikologi, Universitas Muhammadiyah, Malang \\ Email : psi.fadi128@gmail.com
}

\begin{abstract}
Depression generally occurs due to certain life events. Depressed teens tend to experience loneliness, sadness and disappointment in their life. This study aims to determine the relationship between loneliness and depression with the religiosity as the moderator variable. The subjects of this study are 10-13 year old teenagers in "As-Salman" Orphanage in Malang City as many as 32 people. This study uses quantitative methods using UCLA Loneliness scale version 3 to measure loneliness, Beck Depression Inventory (BDI) to measure depression, and Religious Orientatiosn Scale-Revised (ROS-R) to measure religiosity in children. The method of analysis uses Moderated Regression Analysis. The results of the analysis show that there is a direct influence between loneliness and depression in teenagers. Result of correlation coefficient is equal to $p=0,008<0,05$. In addition, it was found that religiosity was able to be a significant mediator on the relationship between loneliness and depression shown with correlation coefficient of $p=$ $0,049<0,05$.
\end{abstract}

Keywords: Loneliness, Religiosity, Depression

\section{PENDAHULUAN}

Setiap individu dapat mengalami perubahan emosi yang erbeda-beda. Salah satu kondisi emosi yang mungkin dialami individu adalah depresi, yaitu kondisi psikologis yang paling umum selama masa hidup normal yang ditandai dengan banyaknya rasa kehilangan dan kekecewaan yang dialaminya (Dhara \& Jogsan, 2013). Depresi dapat menimbulkan kesulitan berkonsentrasi, mempengaruhi fungsi sosial, dan kesulitan dalam penyesuaian diri, bahkan bisa mengarah pada perilaku bunuh diri bagi individu yang mengalami depresi yang berat (Nevid, Greene, Jhonson \& Taylor, 2005: Lubis, 2009).

Anak yatim adalah individu yang membutuhkan kasih sayang dari kedua orang tuanya, dengan kepergian salah satu dari orang tuanya maka seseorang akan mengalami kesepian. Kesepian merupakan keadaan emosional yang membuat individu merasa terasing dari dunia luar (Delisle, 1988). Orang yang mengalami kesepian merasa lemah serta menjadi acuh tak acuh pada ligkungan (Cacioppo, 2006). Orang yang kesepian akan merasa bersalah dan tidak berguna (Ozodasik, 2001), apabila keinginan individu tidak tercapai maka akan berperilaku agresif (Cuceloglu, 1999), cenderung tidak realistis (Genctan, 1993). Kesepian merupakan perasaan yang dirasakan seseorang ketika hubungan sosialnya terganggu. Terganggunya tersebut ketika individu tidak memiliki teman atau hanya mempunyai sedikit teman, maupun individu yang merasa mempunyai hubungan yang tidak harmonis atau kurang sesuai dengan harapan (Sears, 1994).

Usia anak yatim pada kasus ini masih berada pada usia remaja. Masa remaja adalah periode hidup yang rentan dari segi kondisi mentalnya mengalami depresi yang disebabkan oleh kesepian dan harga diri (Ollendick, Selligman, Goza, Byrrd \& Singh, 2003). Beck, Rush, 
Shaw, \& Emery (1979) menyatakan bahwa depresi terjadi karena pandangan yang negatif terhadap diri sendiri, interpretasi yang negatif terhadap pengalam hidup dan harapan yang negatif terhadap diri sendiri dan masa depan. Penyebab depresi pada remaja biasanya terjadi karena adanya perasaan tidak berharga, tidak ada yang menolong dirinya, dan tidak ada harapan.

Dari latar belakang diatas maka peneliti tertarik untuk meneliti tentang hubungan tiga variabel yaitu "Hubungankesepiandengandepresi padaAnak Yatim yang dimoderatoriolehReligiusitas".

Berdasarkan latar belakang di atas, maka dapat dirumuskan permasalahan sebagai berikut: (1) Bagaimana hubungankesepiandengan depresi pada anak yatim?;

Bagaimanahubunganreligiusitas dengandepresi padaanak yatim?; (3) Bagaimanahubunganreligiusitas dengankesepian dandepresi padaanak yatim?

Depresi umunya terjadi karena peristiwa hidup tertentu. Setiap orang mempunyai perbedaan mendasar pada suatu peristiwa yang dihadapi secara berbeda, sehingga dapat memunculkan reaksi yang berbeda antara satu orang dengan dengan yang lain (Stice, Ragan \& Randall, 2004; Bitsika, Sharpley, \& Melhem, 2010; Callahan, Liu, Hetrick, Pucell, Parker, 2012).

Kesepian yaitu kondisi emosi yang muncul ketika seseorang merasa asing, salah paham, atau ditolak oleh orang lain, tidak memiliki teman (Rokach, 2002). Kesepian merupakan masalah psikologis dan didefinisikan sebagai pengalaman yang tidak menyenangkan akibat kurangnya hubungan sosial, kecemasan, kurangnya kemampuan sosialisasi, dan mengarah pada percobaan bunuh diri (Cacioppo, Hawkley, Crawford, Budesson \& Kowalewski, 2002).
Kesepian merupakan reaksi emosi dan kognitif terhadap hubungan sosialyang dimiliki oleh individu. Kesepian disertai emosi negatif, seperti depresi, kecemasan, tidak bahagia, dan tidak puas yang muncul bersamaan dengan rasa pesimis, menyalahkan diri sendiri, dan rasa mau (Baron \& Byrne, 2005).

Religiusitas merupakan gabungan antara kognitif, emosional, motivasional dan aspek perilaku (Hackneys \& Ganders, 2003). Menurut beberapa ajaran agama, syarat untuk mendapatkan keberuntungn, kemenangan, kesejahteraan psikologis yaitu dengan beribadah. Seperti halnya umat muslim melaksanakan shalat untuk mendapatkan ketenangan hati dan ketentraman jiwa. Sependapat dengan hal tersebut Allport (1950) menyatakan bahwa agama merupakan tujuan akhir setiap individu dan harus ditempuh sendiri karena bersifat sangat pribadi, karena agama memberi rasa nyaman, aman, dan memiliki ikatan sosial.

Ada hubungan positifantara kesepian dengandepresi yang dimoderatoriolehvariabel religiusitaspadaanak yatim. Artinyasemakintinggitingkatkesepian seseorangmakasemakintinggi pula kecenderungan mengalami depresi yang dimilikinyabegitupula sebaliknya.

Berdasarkan uraian tersebut di atas maka kerangka pemikiran dari penelitian ini adalah sebagai berikut :

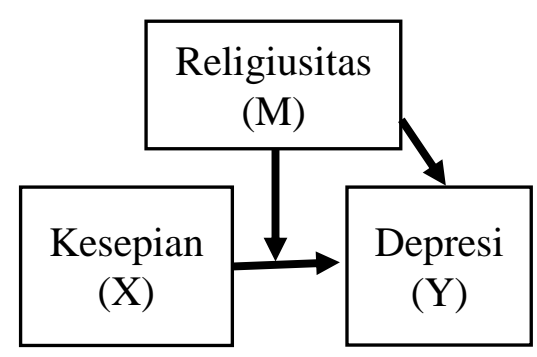

Gambar 1. Kerangka Penelitian 
Hipotesis yang disampaikan dalam penelitian ini adalah : (H1) Ada hubunganpositifantarakesepian dengandepresi; $\quad(\mathrm{H} 2)$ Ada hubunganpositifantarareligiusitas dengandepresi;(H3) Religiusitas mampu memoderatoriantarakesepian dengandepresi.

\section{METODE}

Desain penelitian ini menggunakan metode penelitian kuantitatif. Yaitu metode penelitian yang menjelaskan fenomena dengan menggunakan data numerik, kemudian dianalisis dengan menggunakan statistik untuk mendapatkan temuannya. Prosedur dari metode penelitian kuantitatif yang dipilih adalah desain korelasional. Desain korelasional bertujuan untuk mengukur tingkat asosiasi (atau hubungan) antara dua variabel atau lebih dengan menggunakan metode statistik (Creswell, 2012).

Penelitian ini dilakukan di Pondok Anak Yatim (PAY) As Salman Malang, dengan jumlah responden 32 orang. Peneliti melakukan penelitian ini dengan menyebarkan kuesioner yang diberikan langsung kepada responden. Sampel yang digunakan pada penelitian ini adalah simple random sampling, yaitu pengambilan sampel dari popilasi yang dilakukan secara acak tanpa memperhatikan strata yang ada dalam populasi itu (Sugiyono, 2013). Karakteristik subjek penelitian dapat dilihat pada tabel. 1 .

Tabel.1

\begin{tabular}{lll}
\hline Karakteristik & $\mathrm{N}$ & Porsentase \\
\hline Jenis Kelamin & & \\
Laki-laki & 19 & $59,4 \%$ \\
Perempuan & 13 & $40,6 \%$ \\
\hline Usia & & \\
10 & 7 & $21,9 \%$ \\
11 & 10 & $31,2 \%$ \\
12 & 9 & $28,1 \%$ \\
13 & 6 & $18,8 \%$ \\
\hline Total & 32 & $100 \%$ \\
\hline
\end{tabular}

Kesepian diukur dengan UCLA Loneliness scale version 3 yang dikembangkan oleh Russel. Skala ini berjumlah 20 aitem dengan 4 pilihan jawaban (sangat tidak setuju, tidak setuju, setuju dan sangat tidak setuju). Cronbach's Alpha skala ini sebesar 0.933 .

Religiusitas diukur denganReligious orientatiosn scalerevised (ROS-R)yang dikembangkan oleh Gorsuch \& MacPherson. Skala ini berjumlah 14 aitem dengan 4 pilihan jawaban (sangat tidak setuju, tidak setuju, setuju dan sangat tidak setuju). Cronbach's Alpha skala ini sebesar 0.933 .

Depresi diukur dengan Beck depression inventory (BDI) yang dikembangkan oleh Beck. Skala ini berjumlah 21 aitem dengan 4 pilihan jawaban (sangat tidak setuju, tidak setuju, setuju dan sangat tidak setuju). Cronbach's Alpha skala ini sebesar 0.769 .

Tabel.2

\begin{tabular}{llll}
\hline No & Variabel & $\begin{array}{l}\text { Nilai } \\
\text { Alpha }\end{array}$ & Keterangan \\
\hline 1. & Kesepian $(\mathrm{X})$ & 0.933 & Handal \\
\hline 2. & $\begin{array}{l}\text { Religiusitas } \\
(\mathrm{M})\end{array}$ & 0.933 & Handal \\
\hline 3. & Depresi (Y) & 0.769 & Handal \\
\hline
\end{tabular}

Untukmengujihubunganantarava riabelindependen, variabeldependen, danvariabel moderating digunakananalisis linier berganda, sedangkanuntukmengujihubunganantarv ariabel yang dalamhubungannyatersebutterdapatfakto $r$ yang memperlemahataumemperkuat (variabelmoderasi) pengujiannya menggunakan Moderated Regression Analysis (MRA) yaitu merupakan aplikasi khusus regresi linier berganda dimana dalam persamaan regresinya mengandung unsur interaksi (perkalian dua atau lebih variabel independen) (Liana, 2009). Data dianalisis dengan 
bantuan SPSS 22 for windows. Analisis ini digunakan untuk mengetahui ada hubungan variabel bebas kesepiandengan variabel terikat depresi yang dimoderatoriolehreligiusitas.

Sugiyono (2011:62) menjelaskanbahwa, variabel moderator (Z) adalahvariabel yang memperkuatataumemperlemahhubungan antaravariabelindependendanvariabeldep enden.Dalampenelitianini yang menjadivariabel moderator adalahreligiusitas.Untukmenguji $\quad \mathrm{Z}$ apakahbenarsebagai pure moderator, quasi moderator, ataubukan moderator, dapatdiamatidalamkriteriaberikut:

a. Pure Moderator, apabilapengaruh $\mathrm{Z}$ terhadap $\mathrm{Y}$ pada output pertamadanpengaruhvariabelinteraks ipada output kedua, salahsatunyasignifikan.

b. Quasi Moderator, apabilapengaruh Z terhadap Y pada output pertamadanpengaruhvariabelinteraks ipada output kedua, keduaduanyasignifikan.

c. Bukan Moderator, apabilapengaruh $\mathrm{Z}$ terhadap $\mathrm{Y}$ pada output pertamadanpengaruhvariabelinteraks ipada output kedua, keduaduanyatidakada yang signifikan

\section{HASIL}

$$
\begin{aligned}
& \text { Berdasarkan hasil analisis } \\
& \text { diperoleh deskripsi statistik untuk } \\
& \text { variabel kesepianmemiliki nilai } \mathrm{M}= \\
& 42,16 \text { dengan } \mathrm{SD}=12,609 \text {. Pada variabel } \\
& \text { religiusitasdiperoleh nilai } \mathrm{M}=29,00 \\
& \text { dengan } \mathrm{SD}=9,059 \text { dan pada variabel } \\
& \text { depresidiperoleh nilai } \mathrm{M}=10,19 \text { dengan } \\
& \mathrm{SD}=5,970 \text {. } \\
& \text { Dari hasil analisis (Lampiran 1) } \\
& \text { dapat dilihat bahwa ada tiga persamaan } \\
& \text { regresi dari tiga variabel, yaitu variabel } \\
& \text { kesepian menjadi prediktor }(\mathrm{X}) \text {, variabel } \\
& \text { religiusitasmenjadi variabel mediator } \\
& (\mathrm{M}) \text { dan variabel depresi menjadi } \\
& \text { variabel terikat }(\mathrm{Y}) \text {. Persamaan regresi } \\
& \text { yang pertama antara variabel kesepian }
\end{aligned}
$$

terhadap variabel depresi menunjukkan nilai $R$ atau nilai koefisien regresi sebesar 0,462 , nilai $\mathrm{R}$ Square 0,213 yang menunjukkan sumbangan variabel prediktor sebesar $21,3 \%$ serta nilai $\mathrm{F}$ sebesar 8,141 ( $\mathrm{p}=0,008<0,05)$ yang artinya kesepiandapat memprediksi depresi secara signifikan.

Nilai R persamaan regresi yang kedua antara variabel religiusitasterhadap variabel depresi sebesar 0,568, nilai R Square 0,323 yang artinya sumbangan variabel prediktor terhadap variabel terikat yaitu $32,3 \%$ dengan nilai $F$ sebesar 4,669 ( $p=0,039<$ $0,05)$ yang artinya religiusitas dapat memprediksi depresi secara signifikan. Namun, pada persamaan yang ketiga ketika variabel moderasi dimasukkan, nilai $R$ nya sebesar 0,641 , nilai $R$ Square sebesar 0,411 yang berarti sumbangannya sebesar $41,1 \%$ dengan nilai $\mathrm{F} 4,234$ dan nilai signifikansi $(\mathrm{p}=$ $0,049<0,05)$. Dari hasil persamaan ketiga tersebut dapat dilihat bahwa persamaan moderasi yang terjadi adalah signifikan karena nilai $\mathrm{p}<0,05$ yang artinya ketiga variabel mampu mempengaruhi hubungan antara kesepiandengan depresi.

Hasil uji (Lampiran2) hubungan kesepiandengan depresi menunjukkan ada hubungan yang positif dan signifikan $(\beta=0.462, p=0.008)$ berarti bahwa hipotesis pertama diterima. Hasil uji hubungan religiusitasdengan kesepianmenunjukkan hubungan yang negatif dengan nilai beta sebesar $\beta=$ 0.331 dan signifikansi sebesar $p=0.039$ yang berarti hipotesis kedua diterima.

Dari tersebut dapat diketahui bahwa ada hubungan signifikan antara variabel kesepian dengan depresi dengan nilai signifikansi sebesar 0.004 , dan variabel religiusitas menunjukkan signifikansi antara kesepian dengan depresi, dengan nilai $\mathrm{p}=0,049$ yang berarti bahwa variabel moderator memiliki hubungan secara signifikan dan 
berpengaruh terhadap variabel independen dan dependen. Artinya bahwa aspek religiusitasmemberikan kontribusi dalam menentukan kesepian dan depresi pada anak Panti Asuhan As Salman Malang.

\section{DISKUSI}

Penelitian ini menunjukkan hubungan yang positif antara variabel $X$ dan $\mathrm{Y}$ kesepian dengan depresi pada remaja memiliki hubungan yang signifikan dengan nilai betasebesar $\beta=$ 0.462 dan signifikansip $=0.008<$ 0,05 .Dan pada variabel moderator nilai signifikansi sebesarp $=0,049$ yang artinya variabel moderator mempengaruhi secara signifikan terhadap kedua variabel. Jadi temuan ini menjelaskan bahwa semakin tinggi tingkat kesepian yang dialami remaja maka semakin tinggi pula kecenderungan untuk mengalami depresi begitu pula sebaliknya jika individu tidak merasa kesepian maka cenderung untuk memiliki tingkat depresi yang rendah. Pada penelitian ini religiusitas menjadi variabel moderator antara kesepian dengan depresi, dari hasil analisis dapat diartkan bahwa religiusitas mampu memberikan pengaruh terhadap kesepian dengan depresi akan tetapi berupa pengaruh negatif, jadi semakin tinggi religiusitas seseorang maka akan semakin rendah tingkat kesepian dan depresi yang dialami oleh individu. Hasil analisa tersebut mampu menjawab ketiga hipotesis dan berarti ketiga hipotesis dalam penelitian ini diterima, yaitu ada hubungan positif antara kesepian dengan depresi, ada hubungan positif antara religiusitas dengan depresi dan religiusitas mampu memoderatori antara kesepian dan depresi.

Secara psikologis, remaja yang merupakan anak yatim di panti asuhan jauh lebih mungkin mengalami masalah emosi seperti kesepian, namun belum tentu mempunyai resiko munculnya depresi. Ada pula remaja yang justru mengalami perubahan positif setelah berada dalam lingkungan panti asuhan, yaitu menjadi lebih tegar, mandiri, lebih mendekatkan diri pada tuhan, serta lebih patuh pada orang lain yang tinggal bersama mereka, bahkan ada pula remaja yang tidak mengalami perubahan apapun.

Penelitian mengenai kesepian dengan depresi yang dilakukan oleh Yusuf (2013) menyimpulkan bahwa ada hubungan anara kesepian dengan depresi pada remaja. Artinya semakin tinggi kesepian yang dialami oleh seseorang maka semakin tinggi depresi yang dialaminya. Kesepian dan depresi mampu dimoderatori oleh religiusitas. Menurut Allport (1950) agama atau religiusitas merupakan tujuan akhir setiap individu dan harus ditempuh sendiri karena bersifat sangat pribadi, karena agama memberi rasa nyaman, aman, dan memiliki ikatan sosial. Menurut beberapa ajaran agama, syarat untuk mendapatkan keberuntungn, kemenangan, kesejahteraan psikologis yaitu dengan beribadah.

Seperti halnya umat muslim melaksanakan shalat untuk mendapatkan ketenangan hati dan ketentraman jiwa. Dengan adanya religiusitas maka individu dapat menemukan ketenangan, ketentraman dan kenyamanan dalam hidupnya. Ketika seseorang merasa kesepian dan cenderung untuk depresi, religiusitas sangat berpengaruh dalam menurunkan rasa kesepian dan depresi tersebut. Dengan memahami, mengkaji dan dekat dengan Tuhan mampu membuat individu merasa nyaman.

\section{SIMPULAN}

Dari pembahasan dan hasil penelitian ini dapat disimpulkan bahwa kesepian memiliki hubungan positif yang signifikan dengan depresi dan religiusitas mampu menjadi variabel moderator terhadap kesepian dengan depresi. 
Sehingga ketiga hipotesis dalam penelitian ini diterima.

Setelah diketahui hasil dari penelitian ini yang menunjukkan bahwa kesepian memiliki hubungan positif yang signifikan dengan depresi. Religiusitas mampu memberikan pengaruh yang kuat terhadap kesepian dan depresi, maka peneliti menyarankan kepada : (1) Pengelola atau pengurus Panti Asuhan, untuk selalu menghadirkan suasana aman dan nyaman bagi anak-anak dengan memberikan perlakuan yang sama tanpa ada bedanya antara anak satu dengan yang lain. Selain itu isi kegiatan anak-

\section{DAFTAR PUSTAKA}

Allport, G. W. (1950). The Individual and his religion: A psychological interpretation, New York: Macmillan.

Azwar, S. (2015). Penyusunan Skala Psikologi Edisi 2. Yogyakarta: Pustaka Belajar.

Baron, R. A., \& Byrne, D. (2005). Psikologi Sosial edisi 10. Jakarta: Erlangga.

Beck, A. T., Rush, A. J., Shaw, B. E., \& Emery, G. (1979). Cognitive Therapy of Depression. New York: Guilford Press.

Bitsika, V., Sharpley, C. F., \& Melhem, T. C. (2010). Gender differences in factor scores of anxiety and depression among Australian university students: Implications for counselling interventions. Canadian Journal of Counselling, 44, 51-65.

Cacioppo, J. T., \& Hawkley, L. C., Crawford, L. E., Ermst, J. M., Burleson, M. H., Kowalewski, R. B., \& Bernston, G. G. (2002), Loneliness and Health: Potencial anak panti dengan hal-hal yang positif, seperti segi keagamaan atau hal lain yang bersifat religius secara konsisten dan berkelanjutan; (2) Peneliti selanjutnya, penelitian ini berfokus pada remaja yang notabebenya merupakan anak yatim Panti Asuhan As Salman Malang. Peneliti menyarankan kepada peneliti selanjutnya untuk lebih memperluas ranah penelitian, seperti anak-anak jalanan, dan anak-anak yang mengalami kasus bulliying bahkan bisa juga dikembangkan pada anak yang latar belakang keluarga yang broken home.

mechanisms. Psychosomatic Medicine, 64 (3), 407-417.

Cacioppo, J. T., Huges, M. E., Waite, L. C., \& Thisted, R. A. (2006). Loneliness as a spesific risk factor for depresive symptoms: Crosssectional and longitudninal analysis. Journal Psychology and Aging, 21 (1), 140-151.

Callahan, P., Liu, P., Purcell, R., Parker, A. G., Hertick, S. E. (2012). Evidence map of prevention and treatment interventions of depression in youn people Depression Research and Treatment. Published online, doi: 10.1155/2012/820735.

Delisle, E. J. (1988). What does Solitude Mean to the aged? Canadian Journal on aging. 7, 358-371.

Hackneys, C. H \& Sanders, G. S. (2003) Religiosity and Mental Healt: A Metanalysis of recent. Journal for the scientific Study of Religion, 42 (1) 43-45.

Nevid, J. S., Greene, B., Jhonson, P. A., $\%$ Taylor, S. (2005). Essentials of abnormal psychology in a changing world (Canadian Edition). Toronto, CA: Pearson Education Canada. 
Ollendick, T. H., Selligman, L. D., Goza, A. B., Byrd, D. A., \& Singh, K. (2003). Anxiety and depression in children and adolesencents: A Factor-analitic examination of the tripartite model. Journal of Child and Family Studies, 12, 157-170.

Ozadik, M. (2001). Loneliness of modern people: Konya: Cizgi Publishing.

Rokach, A. (2002). Determinants of loneliness of young adult drug users. The Jurnal of Psychology, 39, 472-480.
Stice, E. Ragan, J. \& Randall, P. (2004). Prospective Relations Between Social Support and Deprssion: Differential Direction of effect for parent and peerSupport? Journal of Abnormal Psychology, 113 (1), 155-159.

Yusuf, N. P., (2016). Hubungan Harga Diri dan Kesepian dengan Depresi pada Remaja. Seminar ASEAN 2nd Psychology \& Humanity. Universitas Muhammadiyah Malang. 386-393.

Lampiran 1.Tabel.4. Uji korelasi

\begin{tabular}{llllll}
\hline Model Summary & & & & & \\
\hline Prediktor & $\mathrm{R}$ & $\mathrm{R}$ Square & $\mathrm{F}$ & Sig. & Kesimpulan \\
& & & & & \\
Kesepian & 0.462 & 0.213 & 8,141 & 0.008 & Signifikan \\
Kesepian, Religiusitas & 0,568 & 0,323 & 4,669 & 0.039 & Signifikan \\
Kesepian, Religiusitas, KxS & 0,641 & 0,411 & 4,234 & 0.049 & Signifikan \\
\hline
\end{tabular}

Lampiran 2.Tabel 5. Uji hubungan antar variabel

\begin{tabular}{|c|c|c|c|c|}
\hline \multicolumn{2}{|c|}{ Model } & $\begin{array}{l}\text { Unstandardized } \\
\text { Coefficients } \\
\text { Std. Error } \\
\end{array}$ & $\begin{array}{l}\text { Standardized } \\
\text { Coefficients } \\
\text { Beta }\end{array}$ & Sig. \\
\hline \multirow[t]{2}{*}{1} & (Constant) & 3,369 & & ,776 \\
\hline & Kesepian &, 077 &, 462 & ,008 \\
\hline \multirow[t]{3}{*}{2} & (Constant) & 4,202 & &, 111 \\
\hline & Kesepian &, 072 & ,482 &, 004 \\
\hline & Religiusitas & ,101 &,- 331 &, 039 \\
\hline \multirow[t]{4}{*}{3} & (Constant) & 11,827 & &, 187 \\
\hline & Kesepian & ,289 & 1,701 & ,009 \\
\hline & Religiusitas & ,426 & ,966 & ,146 \\
\hline & $\mathrm{KxS}$ &, 010 & $-1,856$ & ,049 \\
\hline
\end{tabular}

